\title{
Morphological changes in the beach-foredune system caused by a series of storms. Terrestrial laser scanning evaluation
}

\author{
A. R. Danchenkov ${ }^{1,2}$ and N. S. Belov ${ }^{2}$ \\ Received 28 February 2019; accepted 17 March 2019; published 28 July 2019.
}

The shallow sandy shores of the Curonian Spit (the Russian part of the South-Eastern Baltic) are regularly exposed to storm activity. The Spit foredune serves as a barrier to protect ecosystems and settlements from dangerous hydrometeorological phenomena. Consecutive number of storms resulted in intensive erosion of the foredunes as well as in breaking and flooding of the territories. Quantitative assessment of the beach-foredune system was carried out using terrestrial laser scanning technology. The evaluation included pre-storm measurements of the system condition, as well as a series of post-storm assessments in 2014-2016. This allowed us to obtain multi-temporal, highprecision digital models of the coastal topography for further morphodynamic analysis. The foredune experiences the worst slope erosion changes under the cumulative effects of several events. Prolonged exposure to strong winds of open points, wind surge and waves leads to erosion of the beach, losses in morphology and a shortage of sands. As a result, the dissipation of the wave energy decreases, which may cause erosion of the foredune in some upcoming storm events. This shows that the sequence and timing of various storm events play an important role in the variability of the entire system. The use of high-precision distance measurement tools allows to carry out accurate estimates of sand dynamics in the onshore systems. Such assessments provide information on the morphological response to repeated storm events, including variable exposure parameters for taking effective shore protection solutions. KEYWORDS: Terrestrial laser scanning; accumulative coast; foredune; storm impact; series of storms; hazardous hydrometeorological processes.

Citation: Danchenkov, A. R. and N. S. Belov (2019), Morphological changes in the beach-foredune system caused by a series of storms. Terrestrial laser scanning evaluation, Russ. J. Earth. Sci., 19, ES4003, doi:10.2205/2019ES000665.

\section{Introduction}

The coastal zone, which is an active development zone, is of high importance for current economic ac-

\footnotetext{
${ }^{1}$ Shirshov Institute of Oceanology RAS, Moscow, Russia

${ }^{2}$ Immanuel Kant Baltic Federal University, Kaliningrad, Russia
}

Copyright 2019 by the Geophysical Center RAS. http://rjes.wdcb.ru/doi/2019ES000665-res.html tivities. Also the coastal zone of the sea has a high recreational potential [Kosyan and Pykhov, 1991] The impact of natural processes on the coastal zone, as well as anthropogenic activity, leads to regular changes. Studies of the current coastal zone dynamics make it possible to identify the most dangerous processes, so that to work out a number of measures for the coastal preservation. Technological development offers new research tools that provide accurate timely quantitative characteristics of the dynamics. 
The largest south-eastern coast of the Baltic Sea coastal accumulative form is the Curonian Spit. It starts near the city of Zelenogradsk. The spit stretches north-east, ends in a narrow (400-650 m) strait opposite the city of Klaipeda [Badyukova et al., 2004, Boldyrev and Zenkovich, 1982, Gudelis, 1954, 1959, Kirlis, 1971; Leontiev et al., 1985. Zhindarev et al., 1998.

Natural - man-made origin of the Curonian Spit foredune is its special feature. Separate fragmentary dunes were joined into a solid protective ridge, which was restored on several occasions. Drifting sands used to be fixed with protective sand barriers. From about 1864, the creation of a coastal dune was defined as a special type of protective hydraulic structure. The duty of the foredunes monitoring in 1927 was assigned to the Prussian hydrotechnical department. On the Curonian and Vistula Spit, the measures were taken to enhance the sea-facing slope.

Hazardous hydrometeorological phenomena have a significant impact on the existing natural geomorphological condition of the coastal zone. Intense wave activity destroys the natural makeup of dune complexes, and turns a significant factor in their development. Seasonal storms observed in the water area of the Southeastern Baltic Russian site regularly cause various damage to the existing dune complexes of the Curonian Spit [Bobykina and Stont, 2015, Ryabkova, 1987, Teplyakov and Boldyrev, 2003]. Washout of the composing material changes their morphology, which boosts various processes [Harley et al., 2016, Eabuz, 2014, Sigren et al., 2014: Weymer et al., 2015. The method of terrestrial laser scanning allows us to create a three-dimensional model of the complex relief, which, when compared, provides the basis for assessing the dynamics [Brizi et al., 2015. Montreuil et al., 2004: Szulwic et al., 2015, Volkova et al., 2018. While the monitoring on the territory of the Curonian Spit on the Baltic Sea was carried out, terrestrial laser scanning was used to assess the condition before and after a series of storm events, which makes it possible to calculate the amount of loss and accumulation of sandy material that occurred as a result of the storm impact, as well as redistribution due to activated gravitational processes. The effect of a series of storm events on a shallow accumulative coast was previously studied for the tidal water coasts [Christiansen et al., 2004. Claudino-Sales et al., 2008; Ferreira, 2005.
The technology of terrestrial laser scanning allows to obtain highly accurate results and use 3-D modeling, especially for the areas with complex morphology. This technology is used widely in researching of various natural objects (vegetation [Bienert, 2006; water bodies [Hobbs et al., 2002 , research and monitoring of landslide processes [Abellán et al., 2011; Hobbs et al., 2002. Poulton, 2006]; and coastal zone [Fabbri et al., 2017, Poulton, 2006, Sergeev et al., 2018, Volkova et al., 2018.

\section{Materials and Methods}

\subsection{Terrestrial Laser Scanning Measurements}

The LiDAR technology is based on measuring the time it takes a laser pulse to go from the emitter to the target and back to the receiver. Then the distance to the target is calculated [Wehr and Lohr, 1999. This principle has been used in various types of mobile measuring devices, which include marine laser scanning, airborne laser scanning, and terrestrial laser scanning.

Two Topcon GLS-1500 topographic laser scanners were used in this research. Topcon GLS-1500 is a pulse laser scanner with a measuring range of up to $330 \mathrm{~m}$. The accuracy of measuring distances is up to $4 \mathrm{~mm}$, angles up to $6^{\prime \prime}$. The frequency of scanning is $3000 \mathrm{~Hz}$ (3000 points per second). The scanner is equipped with a class 1 laser, with a wavelength of $1535 \mathrm{~nm}$. The result of the topographic scanner is a point cloud, obtained by combining polar measurements from each of the scanning stations. Point clouds are narrowed through the back-sight on the reference point. The coordinates of each station and reference point were determined with Topcon GR-5 GNSS equipment in the Real Time Kinematic methodology and the differential measurement mode.

Within this study, a total of 10 complex surveys were carried out at the study sites: 6 at site "A" (Museum), of which 3 corresponded to prestorm conditions and 3 to after storm conditions; as well as 4 surveys at site "B" (Morskoye), where 2 pre-storm and 2 post-storm scans were performed. Taking into account the characteristics of the scanning system, the morphology of the coast, the sea 


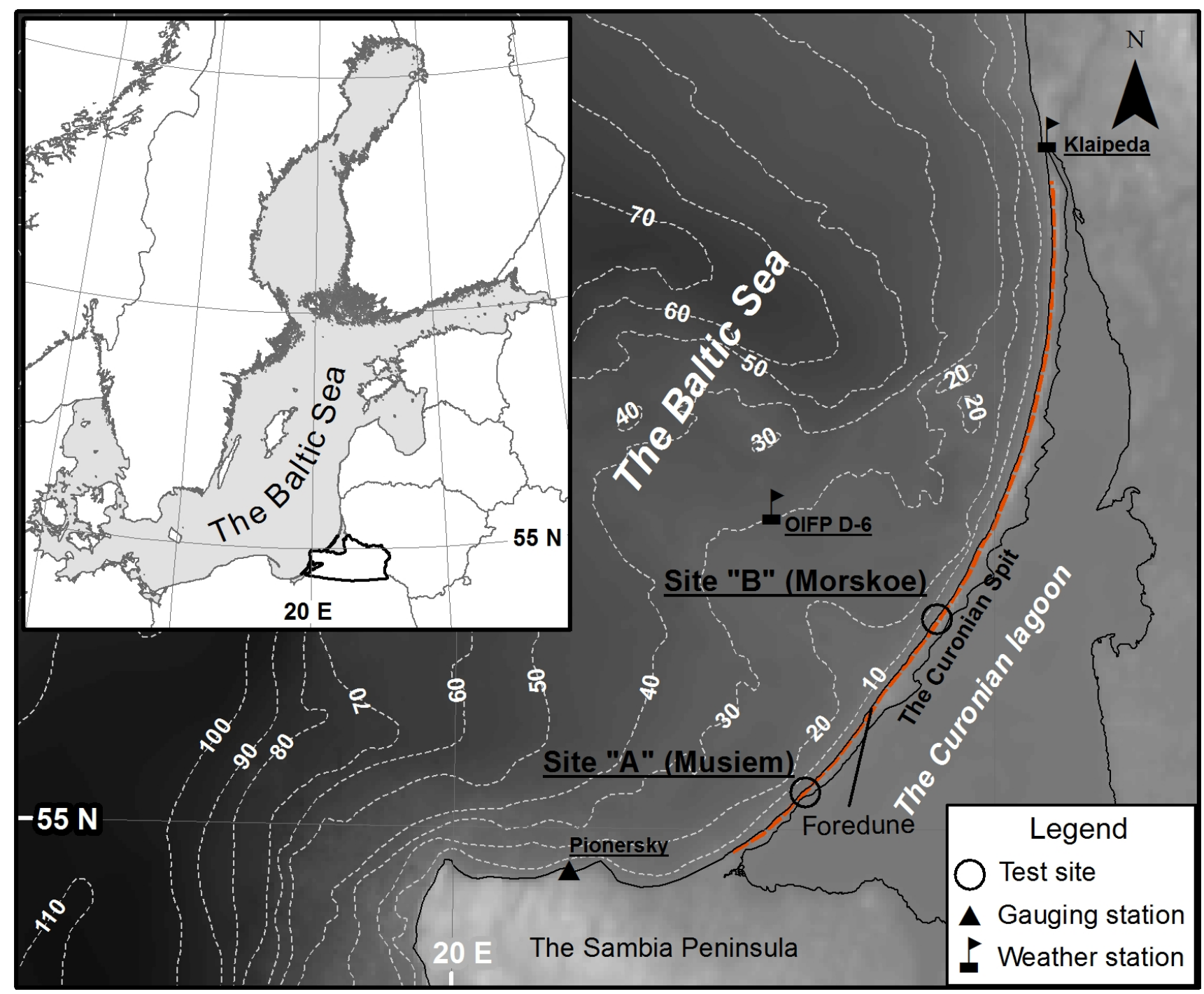

Figure 1. Locations of the two test sites on the Baltic Sea coast (The Curonian spit).

slope of the foredunes, the height of the embryo dune, and the width of the beach, 3-6 scanning stations were carried out within each survey Figure 1).

\subsection{Processing of the Results and Morphological Analysis}

The field materials Topcon GLS-1500 were evaluated in the specialized Topcon Scanmaster software and the following included:

- Consolidation and alignment of individual measurements of DL by means of reverse sighting marks;
- Coordinate station referencing and reverse sighting marks using DGPS data obtained during field work;

- Filtering disturbances, such as vegetation, as well as random obstacles (birds, passers-by);

- Export point cloud in ASCII format for further analysis in GIS.

The digital relief model was built on ESRI ArcGIS 10.0 using the Natural Neighbor interpolation method in raster form and a cell size of $0.2 \mathrm{~m}$, due to its high density and measurement details (less than $3.5 \mathrm{~cm}$ in plan between the measurement points). The construction of digital models was carried out for the implementation of morpholog- 

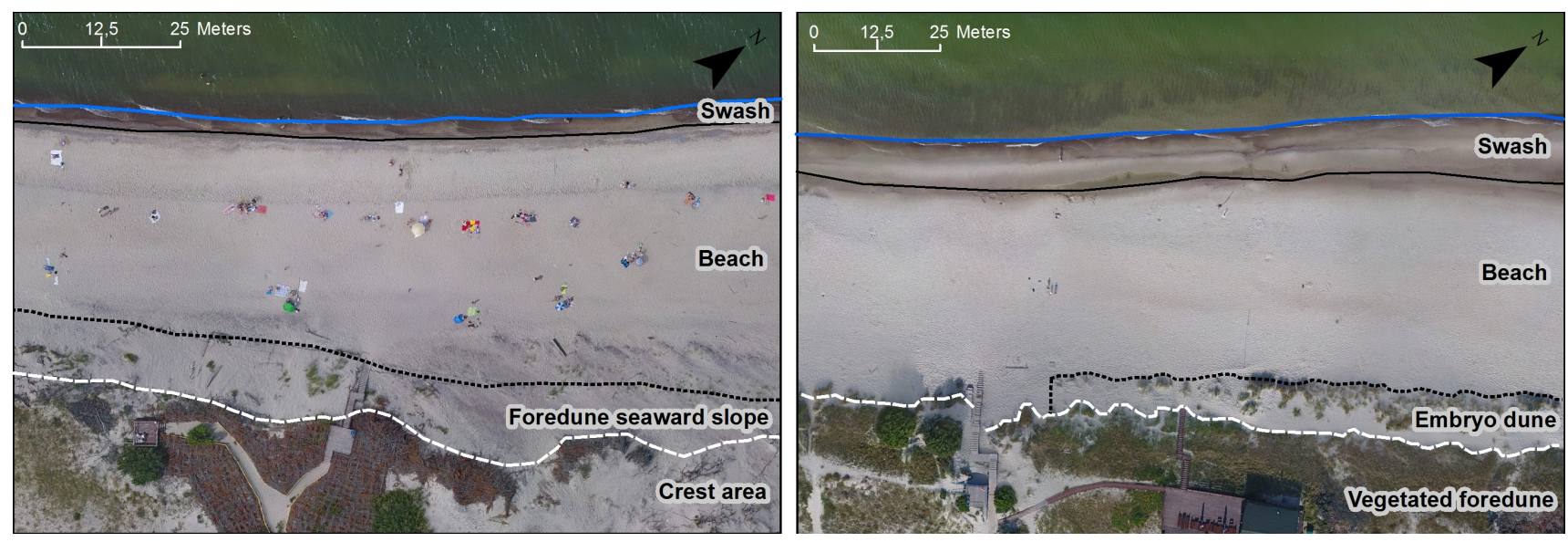

Figure 2. Shore morphological classification as result of DEM and aerial photographs analysis.

ical analysis and zoning. Orthophotographs were used as support materials. The use of ESRI ArcGIS 10.0, visual interpretation of aerial photographs, slopes (Slope tool) identified the following in the sites (Figure 2):

1. Foredune sea slope (active - site "A"; covered with vegetation - site "B"). Borders were defined as areas of the largest height gradient of the digital model surface. [Fabbri et al., 2017. Mitasova et al., 2005;

2. Embryo dune (site "B"). Embryo dune are located in the beach rear part and are significantly affected by wave processes (including storm erosion). They include embryo dune and incipient foredunes, and interact with the beach in an integrated system [Bauer and Sherman, 1999. Embryo dunes are small in size, usually not exceeding $2 \mathrm{~m}$ in height, and are located in the rear part of the beach. Their development is caused by the emergence and growth of pioneer plants, which further leads to the growth of primary foredunes;

3. Beach. Beaches represent a dynamic part of the coastal system in accumulative geomorphological type of the coast. Beach load deposits contribute to aeolian transport alongshore, as well as to the development of foredunes and embryo dunes; they are affected by wave activity. In storm conditions in the beach zone (when the surface slope is not high), the wave energy is dissipated.
4. Swash (splash) zone, however, is not studied in this paper.

\subsection{Hydrometeorological Data and Observations}

Meteorological data were obtained with the Air Hydrometeorological Station (AHMS), which is set $28 \mathrm{~m}$ above sea level on the OIFP D-6 in the open coastal part of the marine area. According to the meteorological measurements of the station, the average and maximum wind speeds (in $\mathrm{m} / \mathrm{s}$ ) are calculated at intervals of 2 and 10 minutes, respectively, and the wind direction (in degrees) averaged over 2 and 10 minutes. Sensor sampling resolution is $30 \mathrm{sec}$. Wind direction and repeatability data were automatically averaged to three-hourly values. We used data for the period 2014-2016, corresponding to the temporal boundaries of the estimated periods of storm activity. During processing, the data were reduced to a standard height of $10 \mathrm{~m}$ above sea level [ $W M O, 2008$. The sea level and wave height information was obtained from the level post of the federal hydrometeorological network in the town of Pionersky (the Kaliningrad region). According to meteorological observations, storm windroses were worked out on the winds stronger than 8 points Beaufort scale [Schwartz, 2005 .

The sea wind directions for the studied areas (azimuth of orientations are $314^{\circ}$ and $305^{\circ}$ ) are in the range of $239^{\circ}-29^{\circ}$ for site "A" and $230^{\circ}-20^{\circ}$ for site "B". The alongshore ones were defined as $209^{\circ}-$ 
Table 1. Hydrometeorological Conditions During TLS Measurement Periods

\begin{tabular}{|c|c|c|c|c|c|c|c|c|c|}
\hline Site & Period & $\begin{array}{c}\text { Total } \\
\text { number } \\
\text { of } \\
\text { storm } \\
\text { events }\end{array}$ & $\begin{array}{l}\text { Event } \\
\text { date }\end{array}$ & $\begin{array}{l}\text { Dura- } \\
\text { tion, } \\
\text { hours }\end{array}$ & Direction & $\begin{array}{l}\text { Wind } \\
\text { speed, } \\
\mathrm{m} / \mathrm{s}\end{array}$ & $\begin{array}{c}\text { Max } \\
\text { height } \\
\text { of the } \\
\text { storm } \\
\text { surge, m }\end{array}$ & $\begin{array}{c}\text { Significant } \\
\text { wave height } \\
\text { (depth } 2 \mathrm{~m}) \\
\mathrm{m}\end{array}$ & $\begin{array}{c}\text { Beach } \\
\text { inunda- } \\
\text { tion } \\
\text { width, } \\
\text { m }\end{array}$ \\
\hline \multirow{8}{*}{$\begin{array}{l}\text { "A" } \\
\text { (Museum) }\end{array}$} & \multirow[t]{6}{*}{ Per. 1} & \multirow[t]{6}{*}{6} & 10.12 .14 & 6 & SSW & 18 & +0.05 & 0.72 & 4.0 \\
\hline & & & 13.12 .14 & 12 & $\mathrm{~S}, \mathrm{~W}, \mathrm{WSW}$ & $19-20.5$ & +0.11 & 1.1 & 16.3 \\
\hline & & & 02.01 .15 & 6 & WSW & 20.5 & +0.31 & 1.1 & 24.4 \\
\hline & & & 04.01 .15 & 12 & NNW & 18-19 & +0.93 & 1.1 & 32.2 \\
\hline & & & 11.01 .15 & 18 & $\mathrm{~W}$ & $18-19.5$ & +0.66 & 1.15 & 28.6 \\
\hline & & & 13.01 .15 & 6 & SSW & 18 & +0.46 & 1.05 & 23.0 \\
\hline & Per. 2 & 1 & 30.03 .15 & 6 & SW, WSW & $19-23.5$ & +0.06 & 0.83 & 7.3 \\
\hline & Per. 3 & 1 & 18.06 .16 & 6 & W, WSW & 20 & 0 & 0.91 & 6.1 \\
\hline \multirow{15}{*}{$\begin{array}{l}\text { "B" } \\
\text { (Morskoye) }\end{array}$} & \multirow[t]{6}{*}{ Per. 1} & \multirow[t]{6}{*}{6} & 02.01 .15 & 6 & WSW & 20.5 & +0.31 & 1.1 & 16.8 \\
\hline & & & 04.01 .15 & 12 & NNW & $18-19$ & +0.93 & 1.1 & 26.3 \\
\hline & & & 11.01 .15 & 12 & $\mathrm{~W}$ & $18-28$ & +0.66 & 0.91 & 22.7 \\
\hline & & & 13.01 .15 & 6 & SSW & 18 & +0.46 & 1.08 & 19.3 \\
\hline & & & 01.02 .15 & 3 & WSW & 18 & +0.41 & 0.87 & 16.5 \\
\hline & & & 30.03 .15 & 6 & SW & $19-23.5$ & +0.06 & 0.84 & 12.4 \\
\hline & \multirow[t]{9}{*}{ Per. 2} & \multirow[t]{9}{*}{9} & 08.11 .15 & 12 & WNW & $19-19.5$ & +0.24 & 0.88 & 9.1 \\
\hline & & & 10.11 .15 & 6 & W & 20 & +0.29 & 1 & 10.4 \\
\hline & & & 19.11 .15 & 6 & WSW & 18 & +0.52 & 1.03 & 14.1 \\
\hline & & & 30.11 .15 & 6 & SW & 19.5 & +0.53 & 1.13 & 15.3 \\
\hline & & & 04.12 .15 & 6 & WSW & 19 & +0.32 & 0.85 & 11.6 \\
\hline & & & $6-7.12 .15$ & 24 & WSW & 18 & +0.56 & 1.14 & 14.6 \\
\hline & & & 22.12 .15 & 6 & WSW & 20 & +0.58 & 1.05 & 26.8 \\
\hline & & & 25.12 .15 & 6 & WSW & 18 & +0.36 & 0.95 & 15.5 \\
\hline & & & 28.01 .16 & 3 & WSW & 18 & +0.12 & 1.11 & 16.0 \\
\hline
\end{tabular}

$239^{\circ}\left(200^{\circ}-230^{\circ}\right)$ and also $29^{\circ}-59^{\circ}\left(20^{\circ}-50^{\circ}\right)[$ Arens et al., 1995. Walker et al., 2009.

Maximum total water level (TWL) was calculated using equation (1)

$$
\mathrm{TWL}=\mathrm{SS}+R_{2} \%
$$

Here: SS - storm surge level; $R_{2 \%}$ - wave run-up.

Wave run-up height was calculated using Mase 1989 equation calibrated for Southeastern Baltic Sea using field measurements by Paprotny et al. 2014 as shown in (2):

$$
R_{2 \%}=1.29 H_{s}\left(\frac{\tan (\alpha)}{\sqrt{H_{s} / L}}\right)^{0.72}
$$

Here: $H_{s}$ - significant wave height, $\alpha$ - beach slope
( $\sin$ of width and relative thickness relation), $L-$ wavelength.

Consequently using equations (1) and (2) beach inundation width was calculated as follows equation (3):

$$
\mathrm{BI}=\mathrm{TWL} \times \cot \left(\arctan \frac{\mathrm{BRT}}{\mathrm{BW}}\right)
$$

Here: TWL - maximum total water level; BRT beach relative thickness (difference between shoreline height and back beach height); BW - beach width.

The main hydrometeorological parameters that were obtained for periods of storm activity are the direction and speed of the winds, the duration and sequence of exposure, the height of the wind surge, 


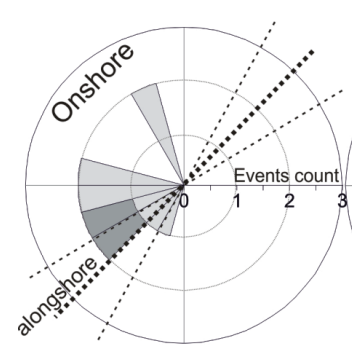

Site "A"

Per. 1

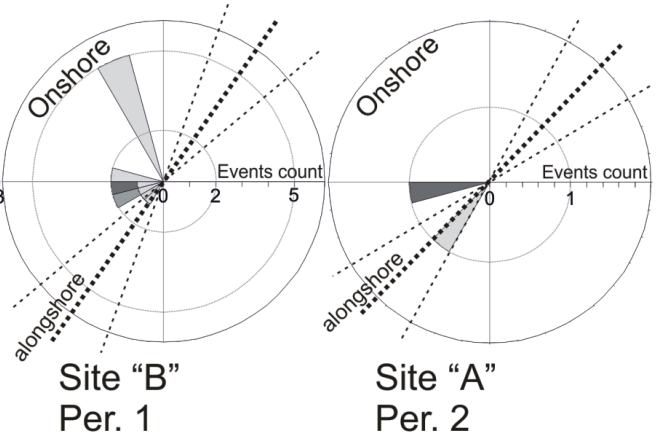

Per. 2

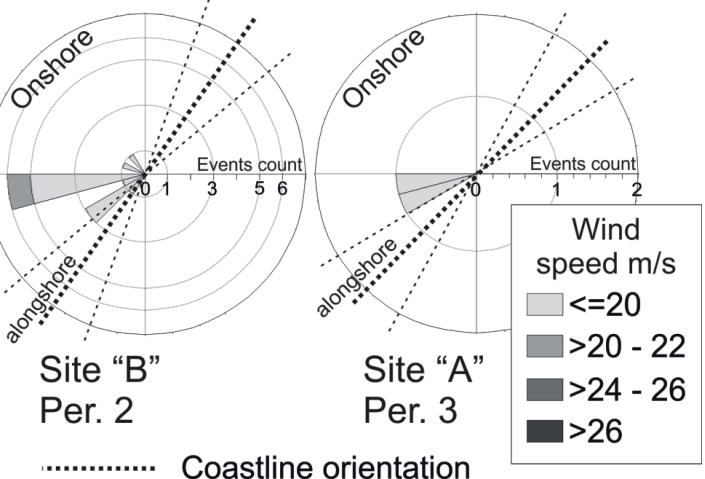

Coastline orientation

Figure 3. Storm windroses durind periods.

significant wave height and related beach inundation width (Table 1).

\section{Results and Discussion}

\subsection{Hydrometeorological Conditions of the Periods}

During the periods under study, the hydrometeorological situation was characterized by conditions that were different in their vectors and structure (Figure 3).

The second and third quarters of the cardinal points prevailed in the 1st period of site of "A", namely, ESE direction (12.8\%), S (12.4\%), SW $(11.8 \%)$, SE (11.4\%). Storm events are characterized by winds of $20-22 \mathrm{~m} / \mathrm{s}$. WSW and SW (one event each) as well as $18-20 \mathrm{~m} / \mathrm{s}$ in the same points. There are 2 events of NNW and $\mathrm{W}$ directions with speeds of $18-20 \mathrm{~m} / \mathrm{s}$. In this period, the storms along the coastline get replaced with storms of open points. The maximum significant waves height reached $1.15 \mathrm{~m}$, with a surge height of $+0.66 \mathrm{~m}$, while the maximum inundation width $32.2 \mathrm{~m}$ was reached at NNW directions.

Period 2 of site "A" is characterized with a predominance of the $\mathrm{W}$ winds with a repeatability of $24.1 \%$, as well as a WNW of $11.7 \%$ and a WSW $10.2 \%$. Storm events are connected with $\mathrm{W}$ winds of $24-26 \mathrm{~m} / \mathrm{s}$, and also a WSW of $18-20 \mathrm{~m} / \mathrm{s}$. In this period, the storm direction from open points is replaced with an alongshore storm. Beach inundation width do not exceed $8 \mathrm{~m}$.

In Period 3 of site "A", $\mathrm{N}$ wind prevailed at $12 \%$,
$\mathrm{W}-11 \%$, and NW $-10.2 \%$. Storm events - W and WSW points with speeds of $18-20 \mathrm{~m} / \mathrm{s}$, single incidence with weak inundation of $6.1 \mathrm{~m}$.

In Period 1 of site "B", the wind situation is characterized by the third quarter of point, W (15.6\%), SW $-12.4 \%$, and WSW $-10.8 \%$. Storm events of NNW directions are characterized by winds of 18 $20 \mathrm{~m} / \mathrm{s}$. In W and WSW points, winds of $18-20$ are observed six times, $20-22 \mathrm{~m} / \mathrm{s}$ and $24-26 \mathrm{~m} / \mathrm{s}$ once. The maximum inundation width is related to the NNW wind directions that caused high surge.

Period 2 of site "B" was dominated by W $(14.3 \%)$ winds, WSW (10.2\%), ESE (10.6\%), NW (9.8\%). Storm events of W points of $20-22 \mathrm{~m} / \mathrm{s}$ once, 18 $20 \mathrm{~m} / \mathrm{s}$ five times, while $\mathrm{SW}-18-20 \mathrm{~m} / \mathrm{s}$ three times. The maximum of the beach inundation width during period is $26.8 \mathrm{~m}$ associated with the WSW direction event.

Based on wind wave field observations, various fetch-growth law variants are known and discussed in many papers (e.g. Battjes et al. 1987, Komen et al. 1996). They can make the following generalizations of factors limiting wind-wave development:

1. Fetch-limited (wave development is not limited by the exposure time, but is limited by the acceleration length);

2. Duration-limited (wave development is not limited by the acceleration length, but is limited by duration of the wind forcing).

In view of these provisions, as well as hydrometeorological observations, it is obvious that storms of open points affect the coast due to the greater length of acceleration, which allows wind waves to develop. At the same time, short duration events 


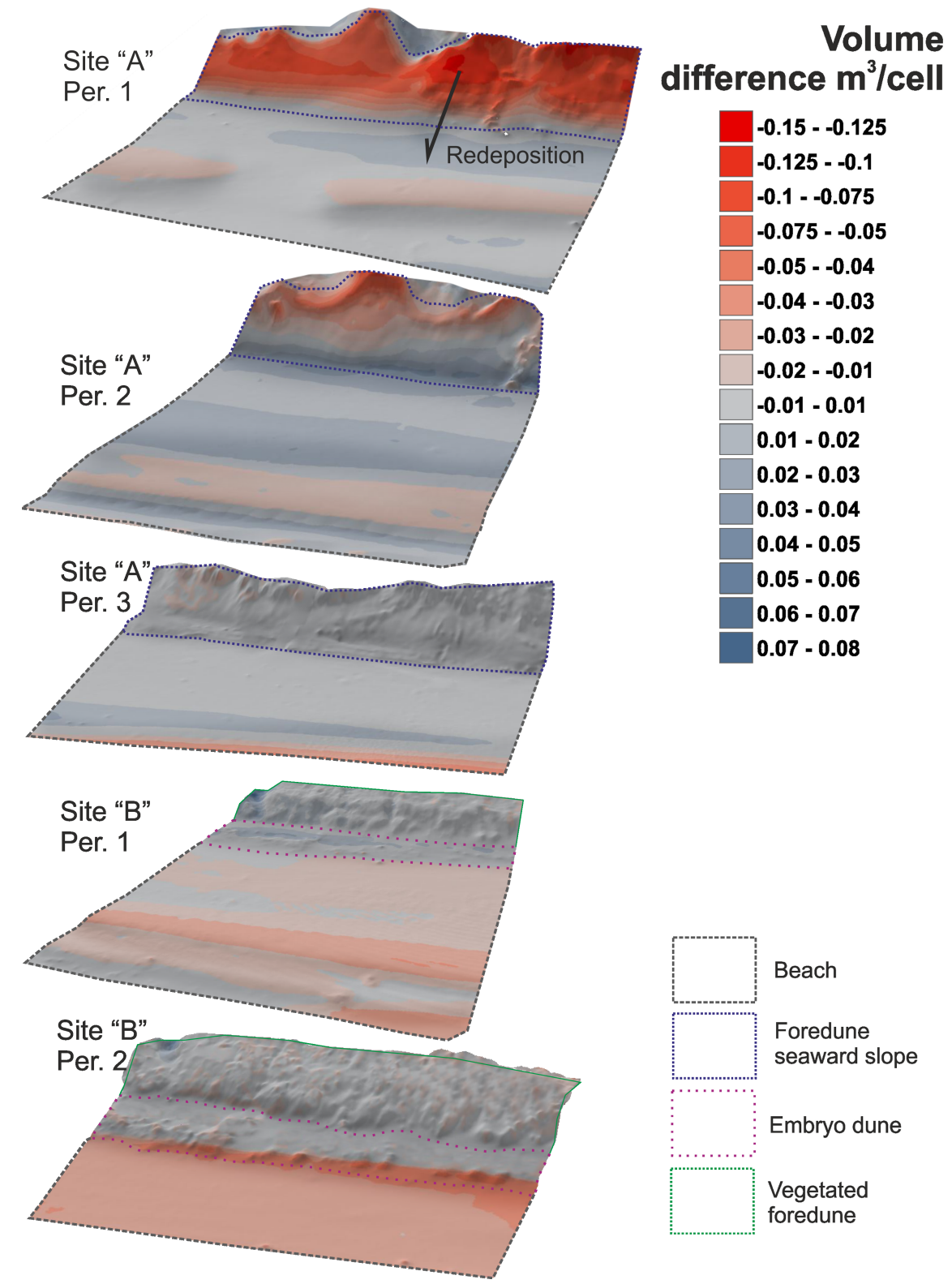

Figure 4. Storm forced sand dynamics at sites during periods The volume of beach changes were obtained from the DEM analysis (Table 2).

(duration-limited) are also a factor initiating inundation of the beach. Due to the difference of in-spit position and exposition for site "A" the WSW direction is fetch-limited $(10-15 \mathrm{~km})$, while for site "B" the acceleration length is already $50 \mathrm{~km}$ what could be enough for the waves development.

\subsection{Results of Terrestrial Laser Scanning}

The measurements obtained during the scan allowed us to construct digital elevation models for both the studied areas: site "A" (Museum) and site "B" (Morskoye). Digital models which are coordinate and altitude referenced to DGPS data enabled to make a comparison of different periods and to evaluate the changes in the series of hydrometeorological events that occurred (Figure 4).

It makes sense to interpret the dynamics of the beach area under the exposure to hydrometeorological hazards in the winter of 2014-2015 for both periods and sites together. Then it is revealed that, against the background of a fairly intense wave erosion of the beach in section 2 (erosion exceeds ac- 
Table 2. Volumetric Characteristics of the Dynamics in the Beach Zone

\begin{tabular}{|c|c|c|c|c|c|c|c|}
\hline Period & $\begin{array}{l}\text { Erosion, } \\
\mathrm{m}^{3} / \mathrm{m}^{2}\end{array}$ & $\begin{array}{l}\text { Accumulation, } \\
\mathrm{m}^{3} / \mathrm{m}^{2}\end{array}$ & $\begin{array}{c}\text { Balance, } \\
\mathrm{m}^{3} / \mathrm{m}^{2}\end{array}$ & $\begin{array}{l}\text { Total erosion } \\
\text { volume, } \mathrm{m}^{3}\end{array}$ & $\begin{array}{l}\text { Total accumulation } \\
\text { volume, } \mathrm{m}^{3}\end{array}$ & $\begin{array}{l}\text { Erosion } \\
\text { area, } \mathrm{m}^{2}\end{array}$ & $\begin{array}{l}\text { Accumulation } \\
\text { area, } \mathrm{m}^{2}\end{array}$ \\
\hline \multicolumn{8}{|c|}{ Site "A" (Museum) } \\
\hline Per. 1 & 0.23 & 0.23 & 0.00 & 180.04 & 297.98 & 796.72 & 1315.84 \\
\hline Per. 2 & 0.05 & 0.27 & 0.22 & 13.94 & 396.98 & 274.72 & 1463.56 \\
\hline Per. 3 & 0.09 & 0.24 & 0.15 & 182.54 & 319.92 & 2023.28 & 1338.72 \\
\hline \multicolumn{8}{|c|}{ Site "B" (Morskoye) } \\
\hline Per. 1 & 0.36 & 0.03 & -0.33 & 1131.53 & 0.16 & 3163.84 & 5.92 \\
\hline Per. 2 & 0.63 & 0.00 & -0.63 & 1240.62 & 0.00 & 1804.36 & 0 \\
\hline
\end{tabular}

Table 3. Volumetric Characteristics of Dynamics in the Zone of Foredunes and Embryonal Dune

\begin{tabular}{lccccc}
\hline Period & $\begin{array}{c}\text { Erosion, } \\
\mathrm{m}^{3} / \mathrm{m}^{2}\end{array}$ & $\begin{array}{c}\text { Accumulation, } \\
\mathrm{m}^{3} / \mathrm{m}^{2}\end{array}$ & $\begin{array}{c}\text { Balance, } \\
\mathrm{m}^{3} / \mathrm{m}^{2}\end{array}$ & $\begin{array}{c}\text { Total erosion } \\
\text { volume } \mathrm{m}^{3}\end{array}$ & $\begin{array}{c}\text { Total accumulation } \\
\text { volume, } \mathrm{m}^{3}\end{array}$ \\
\hline Per. 1 & 1.37 & 0.23 & Site "A" (Museum) & \\
Per. 2 & 0.53 & 0.40 & -1.14 & 1100.58 & 13.32 \\
Per. 3 & 0.09 & 0.07 & -0.13 & 83.43 & 74.83 \\
Per. 1 & 0.13 & 0.22 & Site "B" (Morskoye) & 121.50 & 28.58 \\
Per. 2 & 0.39 & 0.09 & -0.08 & 39.27 & 88.98 \\
\hline
\end{tabular}

cumulation by an order of magnitude) there is no change in balance at $14 \mathrm{~km}$ spot, even with the obvious destruction of the surface coastal ridge. This may indicate a significant redistribution of sand material within the "beach-foredune" system under the impact. Period 2 demonstrates the accumulation of material in the rear and frontal parts, as well as the erosion of the coastal ridge. In general, it is obvious that under the storm waves impact, the beach forms of the relief (in this case, ridges) get leveled and smoothed under the reciprocating action of the waves, which results in a strip-like alternation of erosion and accumulation zones of various intensity.

The volumetric characteristics of erosion and accumulation in the foredune zone of site "A" (Museum), as well as of the embryo dune of site "B" (Morskoye), according to the results of the DM analysis, are given in Table 3 .

Volumetric analysis showed that storms have an impact on the zone of the foredune and embryo dune if the storm events are frequent and open- pointed. Some of the eroded material can probably be redeposited in the beach zone, as well as within the zone itself. The characteristics obtained during the assessment can be applied to evaluate the impact on the beach system and the protective dune ridge.

The volumetric assessment of individual morphological zone dynamics gives a quantitative idea of the drifting sands volume in the time interval between separate measurements, but does not fully characterize the morpholithodynamic process. Another factor is some other processes that alter the end balance of the moved material.

The morphodynamic volume of changes in the conditions of storm activity should include only those changes that directly or indirectly occurred under the influence of dangerous hydrometeorological phenomena. Table 4 shows an example of calculating the morphodynamic volume for Per. 1 storm period taking into account the patterns of erosion and accumulation distribution. The following factors influence the total volume of calculated erosion 
Table 4. The Calculation of the Morphodynamic Volume of Sandy Material Storm Movement in Per. 1 (Site "A" (Museum))

\begin{tabular}{|c|c|c|c|c|c|c|}
\hline \multirow[t]{2}{*}{$\begin{array}{l}\text { Morphological } \\
\text { zone }\end{array}$} & \multirow[t]{2}{*}{$\begin{array}{l}\text { Erosion, } \\
\mathrm{m}^{3}\end{array}$} & \multirow[t]{2}{*}{$\begin{array}{l}\text { Accumulation, } \\
\mathrm{m}^{3}\end{array}$} & \multicolumn{2}{|c|}{$\begin{array}{c}\text { Morphodynamic volume } \\
\text { (storm) }\end{array}$} & \multicolumn{2}{|c|}{$\begin{array}{c}\text { Deduced morphodynamic } \\
\text { volume, } \mathrm{m}^{3} / \mathrm{m}^{2}\end{array}$} \\
\hline & & & $\begin{array}{l}\text { Erosion, } \\
\mathrm{m}^{3}\end{array}$ & $\begin{array}{l}\text { Accumulation, } \\
\mathrm{m}^{3}\end{array}$ & $\begin{array}{l}\text { Erosion, } \\
\mathrm{m}^{3} / \mathrm{m}^{2}\end{array}$ & $\begin{array}{l}\text { Accumulation, } \\
\mathrm{m}^{3} / \mathrm{m}^{2}\end{array}$ \\
\hline Beach & 180.04 & 297.98 & 813.81 & 931.75 & 0.39 & 0.44 \\
\hline Foredune & 1100.58 & 13.32 & 1087.26 & - & 1.26 & - \\
\hline
\end{tabular}

in the period:

1. Transportation of sands from the foredunes during the exposure and its partial redeposition in the beach area while an extensive accumulation zone gets shaped (increasing of the beach relative thickness);

2. Gravitational transportation of sands in the foredune zone after the end of a storm event while the accumulation zone develops.

Thus, the volumes of beach erosion, beach accumulation, and the foredune storm erosion are corrected.

1. Erosion of the beach in Period 1. Due to the displacement of a large amount of sand from the foredunes and its deposits in the beach zone, it is possible to determine the actual volume of storm erosion by the magnitude of the surface part of the swash zone dynamics. Taking into account the volumetric erosion of the coastal ridge $\left(180.04 \mathrm{~m}^{3}\right)$, it was $0.385 \mathrm{~m}^{3} / \mathrm{m}^{2}$ (813.81 $\mathrm{m}^{3}$ in total).

2. Beach accumulation in Period 1. The accumulation volume on the beach due to the redistribution of the eroded foredune material includes two components: the material necessary to achieve a zero balance of erosion and accumulation, without the coastal ridge erosion of $633.77 \mathrm{~m}^{3}$; the volume of accumulation by volumetric assessment of $297.98 \mathrm{~m}^{3}$, that is, the material that was accumulated over the volume of erosion during the wave action. The accumulation of material amounted to a total of $931.75 \mathrm{~m}^{3}\left(0.44 \mathrm{~m}^{3} / \mathrm{m}^{2}\right)$.

3. Foredune storm erosion in Period 1. In the course of the erosion of the foredune sea slope, the volumetric assessment defines volumes of both the erosion and the accumulation. The accumulation zone $\left(13.32 \mathrm{~m}^{3}\right)$ in this case is located at the foot of the eroded slope, in the vicinity of the intensive erosion zone $\left(1100.58 \mathrm{~m}^{3}\right)$, which ascribes the origin of this volume to gravitational redistribution after the end of the storm impact. Thus, the total volume of erosion is $1087.26 \mathrm{~m}^{3}\left(1.263 \mathrm{~m}^{3} / \mathrm{m}^{2}\right)$.

For other periods where there is no obvious redistribution of the material, the morphodynamic volume of the storm movement (if available), which indicates the movement of sands to either the submerged coastal slope or to the swash zone, is volumetrically calculated according to the vectors (erosion or accumulation). Morphodynamic volumes are presented in Table 5 .

Under the conditions of storm exposure, the morphological parts of the coast undergo various changes associated with the movement of the composing material. Such movements result in morphological changes, manifested in a profile change of the coast. Such changes are very different and are in a multiple relationship with both external forces, and its internal structure. Given the volumetric assessment, as well as the subsequent correction and morphodynamic volumes of the beachdune ridge system storm changes, probable scenarios of morphological changes under the influence of storm activity on the Curonian Spit were obtained.

As the analysis showed, the storm impact on the coastal system becomes evident under the combined effect of hydrometeorological factors.

Foredune erosion with the formation of an erosional scarp (which was typical in the Per. 1, site "A") occurs in two main stages. In the first stage, under the conditions of exposure to storm winds of open points and storm surge, there is a consistent erosion of the beach (a decrease in the beach 
Table 5. Deduced Morphodynamic Volume of Storm Erosion

\begin{tabular}{cc}
\hline Period $\quad$ Beach, $\mathrm{m}^{3} / \mathrm{m}^{2}$ & Foredune $(14 \mathrm{~km})$ \\
& or embryo dune \\
& $(42 \mathrm{~km}), \mathrm{m}^{3} / \mathrm{m}^{2}$
\end{tabular}

\begin{tabular}{llc}
\hline & Site "A" (Museum) & \\
Per. 1 & -0.39 & -1.26 \\
Per. 2 & -0.05 & - \\
Per. 3 & -0.09 & - \\
& Site "B" (Morskoye) & \\
Per. 1 & -0.36 & -0.13 \\
Per. 2 & -0.63 & -0.39 \\
\hline
\end{tabular}

volume which increases beach inundation width, respectively). Sustained beach erosion is manifested in the formation and gradual movement of the erosion scarp towards the foredune. In the beach erosion process, the accumulative forms of the beach, the ridges, are also eroded. Gradual erosion lowers the beach mark until reaching the storm profile the beach acquires small slopes, but does not reach a flat plane due to the greater dissipation of wave energy as it moves deeper into the zone. The depth of the beach storm erosion towards the foredune much depends on the duration of the impact of the event (10-12 hours).

The second stage occurs when there is a small gap between the storm events of the first and second stage (7-10 days), as well as the absence of conditions for restoring the accumulative beach profile and increasing its volume. In Period 1 (site "A") the second event occurred within 7 days and was characterized by 18 hour western storm winds of $18-19.5 \mathrm{~m} / \mathrm{s}$, as well as a lower surge $(+0.66 \mathrm{~m})$. Under these conditions, along the storm profile of the beach, the waves reached the foot of the foredunes (beach inundation width was more than $28 \mathrm{~m}$ ), where a small wave-cut notch gradually began to develop. As the notch deepened the overlying foredune, sands collapsed under the gravitation and redeposited on the beach under the wave return motion.

Under the impact of a series of storm events of lesser intensity (typical for Periods 2 and 3 of site "A") accumulative ridges close to the sea edge and subjected to erosion can both increase the amount of erosion losses and create an additional barrier to the wave flow.
The short duration of intense events (3-6 hours), even in intense phenomena does not lead to the development of erosion scarps on the beach, due to duration-limitation factor. This period becomes only the inception phase for the development of the storm profile of the beach and the erosion of the nearby accumulative forms. We should also note that the impact of steady prevailing winds of the western, northwestern and northern points leads to a fairly homogenious erosion of the beach and the retreat of its borders. If the number of western winds grow, this becomes less intensive (up to $-1.2 \mathrm{~m}$ ), and in the case of northern and northwestern winds, it can reach $-11 \mathrm{~m}$, which, however, is not directly related to storm events.

Storm impact in gentle coastal slope conditions (30 $\mathrm{m}$ isobath is located $27 \mathrm{~km}$ from the coastline), as well as the inherent accumulative coast type of site "B" commonly result in the erosion of the embryo dune. Foredune remains stable, and is densely covered with marram grasses.

The impact of the events of open points (for example, in Period 1 of site "B" - a six-hour NNW (18-19 m/s), a nine-hour W (18-19.5 m/s), and also, with an interval of 29 days, an eighteen-hour NNW (18-9 m/s)) under these conditions opens the development of a storm profile and morphological changes like the erosion of the accumulative beach forms. In the conditions of the winter storms of 2014-2015, two generations of these forms were eroded in site "B". The impact on the embryo dune (still underdeveloped) is insignificant, mainly in the wash-off of a small amount of sand with wave swash.

Under another scenario, the steady predominance of westerly and northwesterly winds causes the accumulative types of the coast to be vulnerable to storm effects (beach inundation width was 9-10 m). As mentioned earlier, the steady winds of these directions cause gradual, homogeneous erosion of the beach and the encroachment line approach towards the land edge. In such a situation, early storm period witnesses a shortage of available sand on the beach. Narrow beaches which are not fed by sediments from large slope beaches, see rapid development of the beach erosion scarp affected by the open point winds (e.g. WNW and NNW) even for a short duration (6-8 hours) and its advancement towards the embryo dune. This shapes a storm beach profile and opens the embryo dune for erosion. In Period 2 of site "B" embryo dune erosional scarp 
was developed under the action of a series of short intense events of the WSW direction $(18-21 \mathrm{~m} / \mathrm{s})$.

Such a significant difference in storm changes earlier in different parts of the spit was previously discussed [Kirlis, 1977]. It is related to the difference in surge height, which is provided by coastal slope configuration [Babakov, 2003]. It is also associated with the width and slopes of the beach (wide beaches with significant slopes dissipate wave energy well) [Kirlis, 1990], which, however, can be seen as controversial when considering series of storms, when beaches lose shore deposition during the initial storm events, and new storm events already affect beaches with a strong deposition deficit.

Hurricane (extreme) storms, previously recorded in papers and for which pre-storm and post-storm morphodynamic observations were made, were observed in 1967 and 1982.

In 1967, a storm of 15-20 hours and a wind speed of up to $40 \mathrm{~m} / \mathrm{s}$ caused a wind surge of up to $3 \mathrm{~m}$. [Kirlis, 1990] Shuysky, 1969]. Under these conditions, the foredune of site " $\mathrm{A}$ " has undergone erosion in the volume of $0.38 \mathrm{~m}^{3} / \mathrm{m}^{2}$, while the beach of $0.64 \mathrm{~m}^{3} / \mathrm{m}^{2}$. In site "B", the foredune erosion was $0.33 \mathrm{~m}^{3} / \mathrm{m}^{2}$, the beach erosion was $0.47 \mathrm{~m}^{3} / \mathrm{m}^{2}$.

In 1982 , a storm of up to $40 \mathrm{~m} / \mathrm{s}$ of predominantly a SW direction (alongshore) which lasted 12 days, caused a wind surge of up to 3-3.5 m. [Kirlis, 1990], which led to the erosion of the foredune in site "A" to 0.71 , and 0.91 of the beach; in site "B", the foredune was eroded to $0.27 \mathrm{~m}^{3} / \mathrm{m}^{2}$ and the beach to $0.29 \mathrm{~m}^{3} / \mathrm{m}^{2}$ [Kirlis, 1990; Zharomskis, 1982. This allows to conclude that the duration of hurricane storms exposure plays a key role. The alongshore direction of storm winds brings saturated alongshore deposits drift which is reflected in the dynamics of the spit parts where the underwater bars are developed (section "B") [Kirlis, 1977. Comparatively, the intensity of erosion that occurred during the hurricane storms of 1967 and 1982 does not exceed the intensity of the erosion of the Period 1 in site "A", and Period 2 in site "B" in spite of half the wind force $(18-23 \mathrm{~m} / \mathrm{s}$ against $40 \mathrm{~m} / \mathrm{s}$ ), or a significant difference in the height of the storm surge (0.94 $\mathrm{m}$ against $3 \mathrm{~m}$ ).

In comparison to earlier observations of storm periods from July 1975 to July 1976, 26 events of mainly W-SW directions were recorded. Over the period, in site "A" the beach erosion was of $0.3 \mathrm{~m}^{3} / \mathrm{m}^{2}$, the foredunes of $0.9 \mathrm{~m}^{3} / \mathrm{m}^{2}$, and on the site " $\mathrm{B}$ " it was not observed (for both morphological zones $+0.1 \mathrm{~m}^{3} / \mathrm{m}^{2}$ ) [Kirlis et al., 1981]. In the period from July 1976 to July 1977, there were 18 events of predominantly N-NW directions, and erosion was observed only on the beach; in the site "A" it was $0.03 \mathrm{~m}^{3} / \mathrm{m}^{2}$; while in site "B" $0.06 \mathrm{~m}^{3} / \mathrm{m}^{2}$ [Kirlis et al., 1981], which, however, may be associated with the impact of only the latest storm events. Comparison of these results with the results of this work, as well as the hurricane storms of 1967 and 1982, allow us to conclude that a series of storms of non-exclusive strength can ultimately cause the erosion of beaches and foredunes with greater intensity than a hurricane storm which lasts longer than any of the events of the series.

\section{Conclusion}

The research focused on the volumetric variability of the beach - protective dune ridge system under storm conditions of a synoptic scale. Earlier estimates of storm dynamics used to be related to the changes in linear characteristics. The current study produced highly accurate calculations of the volume dynamics of sandy material.

Exposed to storm conditions, the morphological parts of the coast undergo various changes associated with the movement of the composing material. Such movements result in a variety of morphological changes, manifested in a coastal profile change. These changes are various and are in a multiple relationship with both external forces, and with its internal structure, formed by the previously applied effects, mainly expressed in beach sediments volumes. For determining the scenarios of morphological changes under the influence of storm activity, the volumes of morphodynamic changes were obtained based on the volumetric approach.

All this allows the following conclusions:

1. The main factor of morphological variability during storm activity is the wave runups and storm surges causing an increase of beach inundation width. The maximum value is reached under the influence of the storm winds of open points of great duration, mainly of western to northern points, because not fetch-limited; 
2. Storms along the coastline directions with high speeds $(20-24 \mathrm{~m} / \mathrm{s})$ due to fetch limitation cause lower wave run-up and surge heights. However, these speeds are enough to start the formation of a storm profile on a part of a beach. They create favorable topographic conditions for subsequent storm events (the reduction of beach in volume and the reduction of its slope);

3. The foredune erosion during storms of an average strength occurs due to the cumulative effect with the occurrence of storm events, being expressed in two main stages. In the first stage, conditions are created for the foredunes to reach the border - a low storm profile of the beach, and, with sufficient duration or a repetition of the storm event - to reach the boundary of the foredunes, with the formation of a small wave-cut recess that encourages the collapse of the foredune material. This material can be redistributed to the beach, while maintaining its storm profile;

4. For accumulative shores, hazardous conditions for storm erosion occur when exposed to the steady winds of open points. This leads to a reduction in the volume of the beach, accompanied by its retreat. As a result of this process, there is a zone of significant volume contrast at the border of the swash and beach zones, which creates morphological prerequisites for the formation of a beach erosion scarp;

5. A series of storms of an average strength can, in the end, cause the erosion of beaches and foredunes with greater intensity than a hurricane storm, which lasts longer than any individual event of a series of storms;

6. The average turning point of beach erosion for initiating the foredune erosion on a 14 kilometre site is between $0.2-0.4 \mathrm{~m}^{3} / \mathrm{m}^{2}$, for a $42-\mathrm{km}$ site to affect the embryo dune it is between $0.3-0.6 \mathrm{~m}^{3} / \mathrm{m}^{2}$, depending on the size of the accumulative beach forms.

Acknowledgments. The study was done with a support of the state assignment of IO RAS (Theme No. 0149-2019-0013).

\section{References}

Abellán, A., J. M. Vilaplana, J. Calvet, et al. (2011), Rockfall monitoring by Terrestrial Laser Scanning case study of the basaltic rock face at Castellfollit de la Roca (Catalonia, Spain), Natural Hazards and Earth System Sciences, 11, No. 3, 829-841, Crossref

Arens, S. M., H. M. E. Van Kaam-Peters, et al. (1995), Air flow over foredunes and implications for sand transport, Earth Surface Processes and Landforms, 20, 315-332, Crossref

Babakov, A. N. (2003), Spatio-temporal structure of currents and deposit transport in the coastal zone of the south-eastern Baltic: Sambia Peninsula and Curonian Spit, PhD thesis in geography, p.273, KGU press, Kaliningrad. (in Russian)

Badyukova, E. N., L. A. Zhindarev, S. A. Lukianova, G. D. Solovieva (2004), Geomorphology of the Curonian Spit, Coastal Zone of the Sea: Morpholithodynamics and Geo-Ecology: Conference papers, Prof. Orlyonok V. V. (ed.) p.65-70, KGU press, Kaliningrad. (in Russian)

Battjes, J. A., T. J. Zitman, L. H. Holthuusen (1987), A reanalysis of the spectra observed in JONSWAP, Journal of Physical Oceanography, 17, No. 8, 12881295, Crossref

Bauer, B. O., $\quad$ D. J. Sherman (1999), Coastal dune dynamics: problems and prospects, Aeolian Environments, Sediments and Landforms p.71-104, Wiley, Chichester.

Bienert, A., S. Scheller, E. Keane, G. Mullooly, F. Mohan (2006), Application of terrestrial laser scanners for the determination of forest inventory parameters, International Archives of Photogrammetry, Remote Sensing and Spatial Information Sciences, 36, No. 5, 1-5.

Bobykina, V. P., Zh. I. Stont (2015), Winter Storm Activity in 2011-2012 and Its Consequences for the Southeastern Baltic Coast, Water Resources, 42, No. 3, 371-377, Crossref

Boldyrev, V. L., V. P. Zenkovich (1982), The Baltic Sea shores, USSR Geomorphology, vol. 5 p.214-218, Science, Moscow. (in Russian)

Brizi, E., A. Brunetti, S. Martino, C. Margottini, P. Mazzanti, G. S. Mugnozza (2015), Terrestrial Laser Scanning survey of the Sugano cliff (Orvieto, Italy) for slope stability analyses, Rend. Online. Soc. Geol. It., 35, 38-41, Crossref

Christiansen, M. B., R. G. D. Davidson-Arnott (2004), Rates of landward sand transport over the foredune at Skallingen, Denmark and the role of dune ramps, Danish Journal of Geography, 104, No. 1, 31-43, Crossref

Claudino-Sales, V., P. Wang, M. H. Horwitz (2008), Factors controlling the survival of coastal dunes during multiple hurricane impacts in 2004 and 2005: Santa Rosa barrier island, Florida, Geomorphology, 95, 295-315, Crossref 
Fabbri, S., B. M. Giambastiani, F. Sistilli, F. Scarelli, G. Gabbianelli (2017), Geomorphological analysis and classification of foredune ridges based on Terrestrial Laser Scanning (TLS) technology, Geomorphology, 295, 436-451, Crossref

Ferreira, Ó (2005), Storm groups versus extreme single storms: predicted erosion and management consequences, Journal of Coastal Research, 42, 221227.

Gudelis, V. K. (1954), Some data on the structure and development of the Kursiu-Neriya, Papers of the Institute of Oceanology, Volume X p.62-69, IO AS USSR, Moscow.

Gudelis, V. K. (1959), Geological and physiographic conditions of the Gulf of Kursiu-Mares and the bay border territory, Kursiu-Mares p.7-45, Lithuanian Academy of Science Press, Vilnius.

Harley, M. D., A. Valentini, C. Armaroli, L. Perini, L. Calabrese, P. Ciavola (2016), Can an earlywarning system help minimize the impacts of coastal storms? A case study of the 2012 Halloween storm, northern Italy, Natural Hazards and Earth System Sciences, 16, No. 1, 209-222, Crossref

Hobbs, P. R. N., B. Humphreys, J. G. Rees, D. Tragheim, L. Jones, A. Gibson, R. Airey (2002), Monitoring the role of landslides in "soft cliff" coastal recession, Instability Planning and Management p.589-600, Thomas Telford, London.

Kirlis, V. I. (1971), Some features of the seashore dynamics of the Kursiu-Neriya shores, Lithuanian Academy of Science Press, Series B, 4, No. 67, 211224.

Kirlis, V. I. (1977), Some features of surge and surge events in the southeastern part of the Baltic Sea in modern hydrometeorological conditions, Lithuanian Academy of Science Press, Series B, 4, No. 101, 129-134.

Kirlis, V. I. (1990), Impact of hurricane (extreme) storms on the shallow sandy shores of the southeastern part of the Baltic Sea, The Issues of Coastal Dynamics and the Baltic Sea Paleogeography, 1, No. 1, 192.

Kirlis, V. I., $\quad$ S. A. Mochekene, Z. A. Yanukonis (1981), Intensity of storm changes of the beach and protective dunes in the shallow sandy coast of the southeastern part of the Baltic Sea, Lithuanian Academy of Science Press, Series B, 1, No. 122, 101-107.

Komen, G. J., L. Cavaleri, et al. (1996), Dynamics and Modelling of Ocean Waves, 554 pp. Cambridge University Press, Cambridge, UK.

Kosyan, R. D., N. V. Pykhov (1991), Hydrogenic Movement of Sediments in the Coastal Zone of the Sea, 280 pp. Science, Moscow.

Łabuz, T. (2014), Erosion and its rate on an accumulative Polish dune coast: the effects of the January 2012 storm surge, Oceanologia, 56, No. 2, 307-326, Crossref

Leontiev, O. K., $\quad$ L. A. Zhindarev, O. I. Ryabkova
(1985), On the morphology and genesis of the Curonian Spit (Kursiu-Neriya), Geomorphology, No. 4, 86-93.

Mase, H. (1989), Random wave runup height on gentle slope, Journal of Waterway, Port, Coastal, and Ocean Engineering, 115, No. 5, 649-661, Crossref

Mitasova, H., M. Overton, R. S. Harmon (2005), Geospatial analysis of a coastal sand dune field evolution: Jockey's Ridge, North Carolina, Geomorphology, 72, No. 1-4, 204-221, Crossref

Montreuil, A.-L., J. Bullard, J. H. Chandler, J. Millett (2004), Decadal and seasonal development of embryo dunes on an accreting macrotidal beach: North Lincolnshire, UK, Earth Surface Processes and Landforms, 38, No. 15, 1851-1868, Crossref

Paprotny, D., P. Andrzejewski, P. Terefenko, K. Furmańczyk (2014), Application of empirical wave run-up formulas to the Polish Baltic Sea coast, PLOS One, 9, No. 8, e105437, Crossref

Poulton, C. V., J. Lee, P. Hobbs, L. Jones, M. Hall (2006), Preliminary investigation into monitoring coastal erosion using terrestrial laser scanning: case study at Happisburgh, Norfolk, Bulletin of the Geological Society of Norfolk, 56, No. 1, 45-64.

Ryabkova, O. I. (1987), Dynamics of the coast of the Sambian Peninsula and the Curonian Spit in connection with the problems of coast protection, Diss. Cand. Geogr. Sciences, p.306, Moscow State University, Moscow.

Schwartz, M. L. (2005), Encyclopedia of Coastal Science, 1213 pp. Springer, Dordrecht. Crossref Sergeev, A., D. Ryabchuk, V. Zhamoida, I. Leontiev, A. Kolesov, O. Kovaleva, K. Orviku (2018), Coastal dynamics of the eastern Gulf of Finland, the Baltic Sea: toward a quantitative assessment, Baltica, 31, No. 1, 49-62, Crossref

Shuysky, Yu. D. (1969), On the impact of severe storms on the sandy shores of the Eastern Baltic, Oceanology, 9, No. 3, 475-478.

Sigren, J., J. Figlus, A. Armitage (2014), Coastal sand dunes and dune vegetation: Restoration, erosion, and storm protection, Shore 83 Beach, 82, No. $4, \quad 5-12$.

Szulwic, J., P. Burdziakowski, A. Janowski (2015), Maritime Laser Scanning as the Source for Spatial Data, Polish Maritime Research, 22, No. 4, 9-14, Crossref

Teplyakov, G. N., $\quad$ V. L. Boldyrev (2003), Formation, state and problems of preserving the landscapes of the Curonian Spit, Problems of Studying and Protecting the Natural and Cultural Heritage p.20-40, NIA-Nature, Moscow.

Volkova, I. I., T. V. Shaplygina, N. S. Belov, A. R. Danchenkov (2018), Eolian coastal-marine natural systems in the Kaliningrad Region, Terrestrial and Inland Water Environment of the Kaliningrad Region p.147-177, Springer, Cham. Crossref 
Walker, I. J., P. A. Hesp, R. G. D. Davidson-Arnott, B. O. Bauer, S. L. Namikas, J. Ollerhead (2009), Responses of three-dimensional flow to variations in the angle of incident wind and profile form of dunes: Greenwich Dunes, Prince Edward Island, Canada, Geomorphology, 105, 127-138, Crossref

Wehr, A., U. Lohr (1999), Airborne laser scanning - an introduction and overview, ISPRS Journal of photogrammetry and remote sensing, 54, No. 2-3, 68-82, Crossref

Weymer, B. A., C. A. Houser, J. R. Giardino (2015), Poststorm Evolution of Beach-Dune Morphology: Padre Island National Seashore, Texas, Journal of Coastal Research, 31, No. 3, 634-644, Crossref

WMO (2008), Guide to Meteorological Instruments and Methods of Observation, $716 \mathrm{pp}$. Secretariat of the World Meteorological Organization, Geneva, Switzerland.

Zharomskis, R. (1982), Uraganiniu audru poveikis Lietuvos pajuriui, Geografinis Metrastis, 20, 89-97.

Zhindarev, L. A., A. Sh. Khabidov, A. K. Trizhno (1998), Uraganiniu audru poveikis Lietuvos pajuriui, Dynamics of Sandy Sea Shores and Inland Waters, Kaplin P. A. (ed.) p.271, Nauka, Novosibirsk.

A. R. Danchenkov, Shirshov Institute of Oceanology, Russian Academy of Science, Moscow, Russia, 36 Nahimovskiy prospekt, 117997 Moscow, Russia. (aldanchenkov@mail.ru) 